\title{
Peranan Masyarakat Mengangkat Perekonomian Kampung Kumuh Berbasis Kampung Ramah Lingkungan Sebagai Bagian Untuk Dijadikan Sebagai Desa Wisata
}

\author{
Erni Prasetiyani \\ Prodi Ilmu Administrasi Publik - Institut STIAMI \\ Email: erasetiya@gmail.com, erni@stiami.ac.id
}

\begin{abstract}
Identical slums with residents far from the word prosperous and uneducated. Slums have become a common sight of densely populated cities that are urbanites. The Green Village program issued by the Bogor district as a form of concern for the environment of the population which is fairly dense and slum population due to lack of greening land and lack of awareness of environmental cleanliness. The research method used is qualitative. Kampung Gunung Geulis Bogor is one of the villages that has changed the paradigm from a slum village to an Eco-friendly Village (KRL). Residents receive education about the importance of greening and environmental cleanliness by forming a waste bank and recycling waste into useful products. From KRL, the population is able to produce compost and plant crops with used media. Compost and plants are currently consumed by themselves to meet the needs of residents. The excess production has the potential to be sold in the market as additional income for citizens. This target is a long-term program so that citizens will prosper independently. In addition raising the economy of the citizens, KRL creates this village as an alternative tourism village in Kabupaten Bogor.
\end{abstract}

Keywords

Green and environmental cleanlines.

Tourism village

\section{Pendahuluan}

\subsection{Latar Belakang}

Gerakan sosial zero waste saat ini menjadi sebuah alternatif mengurangi dan memerangi sampah lingkungan dengan mengubahnya menjadi suatu produk yang mempunyai nilai tambah. Zero Waste Lifestyle (Gaya Hidup Nol Sampah) dianggap mampu mengubah pola pikir dan perilaku positif dalam mengolah sampah rumah tangga (Komari et al., 2011). Beberapa warga di lingkungan terendah setingkat RW sudah mampu mengolah sampah lingkungan dengan mendirikan Bank Sampah. Dari sampah dapat dihasilkan limbah yang masih dapat didaur ulang dan tidak dapat didaur ulang. Sampah yang masih dapat didaur ulang ada yang disortir untuk dijual, ada yang digunakan sendiri untuk kepentingan lingkungan. Limbah sampah yang tidak dijual kemudian diolah menjadi produk ramah lingkungan seperti sampah botol minuman, di mana setelah diolah dengan kreatif dapat dijadikan pot tanaman, penyangga tanah, dan tutupnya dijadikan pengganti material konblok.

Di Kabupaten Bogor, gerakan sosial Zero Waste Lifestyle dimanifestasikan menjadi sebuah Gerakan Kampung Ramah Lingkungan. Kampung Ramah Lingkungan sudah dicanangkan Pemerintah Kabupaten Bogor melalui Rancangan Pembangunan Jangka Menengah Daerah 2013 - 
2018. Dalam situs bkgc.bogorkab.go.id, Kampung Ramah Lingkungan adalah suatu lokasi yang masyarakatnya melakukan upaya atau tindakan nyata dalam perlindungan dan pengelolaan lingkungan hidup secara terstruktur dan berkesinambungan. Tujuan dari Kampung Ramah Lingkungan adalah untuk mendorong Pemerintah Daerah, Pelaku Usaha dan masyarakat lokal untuk memahami permasalahan lingkungan dan dampaknya, serta melakukan tindakannya secara proaktif yang berkontribusi kepada upaya perlindungan dan pengelolaan lingkungan hidup. Elemen-elemen Kampung Ramah Lingkungan (KRL), yaitu:

- Pengendalian kekeringan, banjir dan longsor melalui kegiatan penghijauan, pengelolaan sampah dan pembuatan lubang biopori;

- Penyediaan bank sampah dan kreasi sampah daur ulang;

- Penyediaan tanamah vertikultur dengan memanfaatkan lahan pekarangan rumah demi terciptanya Kampung Ramah Lingkungan;

- Edukasi lingkungan kepada masyarakat;

Pariwisata berbasis kearifan lokal dan menyatu dengan alam menjadi tren terkini dalam meningkatkan pendapatan suatu daerah yang memang secara tidak langsung mengangkat pula ekonomi rakyat.

\subsection{Teori Gerakan Sosial}

Menurut Sztompka dalam (Putry, 2004), Gerakan Sosial adalah tindakan kolektif atau tindakan bersama yang diorganisir secara longgar, yang tidak berlembaga untuk menghasilkan perubahan di masyarakat. Sedangkan menurut Blumer dalam (Taib et al., 2010) yang dimaksud dengan Gerakan Sosial adalah menentukan suatu tatanan baru dalam kehidupan.(Sadikin, 2004) menjelaskan secara rinci mengenai karakter Gerakan Sosial di masyarakat, yaitu : 1) Gerakan Sosial adalah satu bentuk perilaku kolektif; 2) Gerakan Sosial senantiasa berupaya membuat suatu perubahan sosial atau untuk mempertahankan suatu kondisi; 3) Gerakan Sosial tidak identik dengan gerakan politik yang terlibat dalam perebutan kekuasaan secara langsung; 4) Gerakan Sosil merupakan perilaku kolektif yang terorganisir baik formal maupun tidak formal; 5) Gerakan Sosial merupakan gejala yang lahir dalam kondisi masyarakat yang konfliktual.

\subsection{Desa Wisata}

Desa wisata dalam (Arismayanti et al., 2015) merupakan suatu desa yang memiliki ciri khas tersendiri yang mencerminkan keaslian desanya, baik dari aspek kehidupan sosial budaya, adat istiadat sehari-hari, arsitek bangunan dan struktur tata ruang desa, dan berpotensi untuk dikembangkan sebagai destinasi pariwisata, misalnya atraksi, kuliner, suvenir, dan kebutuhan pariwisata lainnya.

Pengembangan suatu wilayah menjadi desa wisata harus direncanakan dengan matang dan hatihati agar dapat dikontrol dengan baik oleh penduduk lokal. Aspek-aspek yang diperlukan untuk pengembangan suatu wilayah menjadi desa wisata antara lain:

a. Melengkapi sarana dan prasarana wisata dalam skala kecil disertai dengan pelayanan yang memadai. Sarana dan prasarana dengan skala kecil diharapkan sesuai dengan kemampuan modal penduduk lokal.

b. Kepemilikan sarana dan prasaranan wisata dapat dimiliki secara bersama-sama oleh warga dapat pula dimiliki oleh perorangan yang merupakan penduduk setempat.

c. Pengembangan desa wisata didasarkan pada ciri khas yang melekat yang merupakan budaya tradisional yang dimiliki namun demikian tidak menutup kemungkinan untuk mengembangkan sesuatu yang tidak ada menjadi ada, pengembangan desa wisata seperti ini menuntut kreativitas penduduk lokal untuk memajukan lingkungannya.

Dengan adanya desa wisata akan tercipta interaksi antara kebutuhan wisatawan dan pemenuhan kebutuhan tersebut oleh penduduk, sehingga terjadi efek domino dimana akan terjadi transaksi ekonomi baik jasa maupun barang. Manfaat utama dari desa wisata bagi pemberdayaan penduduk, yaitu: 
a. Pengunjung/wisatawan mempunyai kebutuhan akan penginapan maka terciptalah homestay, hostel penginapan skala kecil yang memanfaatkan rumah-rumah penduduk lokal.

b. Kebutuhan makanan dan minuman tercipta seiring pertumbuhan pengunjung/wisatawan yang hadir ke desa wisata. Makanan dan minuman tradisional yang merupakan ciri khas kuliner desa wisata dapat dihadirkan sebagai pilihan wisatawan selain tentunya makanan standar nusantara lainnya.

c. Sarana dan prasaranan lain yang menunjang lainnya seperti lahan parkir, lokasi spot menarik, toilet umum, jaringan wifi.

d. Terciptanya lapangan pekerjaan bagi penduduk lokal dan menggeliatnya perekonomian rakyat merupakan efek utama yang disasar dari munculnya desa wisata di satu wilayah. Warga secara mandiri mampu membangun desa yang tadinya tidak produktif menjadi lebih produktif dengan memanfaatkan lahan sendiri secara optimal.

\subsection{Gerakan Sosial Kampung Ramah Lingkungan}

Gerakan Kampung Ramah Lingkungan sedang digiatkan saat ini dengan sasaran daerah perkotaan, yang kurang dalam mengelola lingkungannya dan lahan penghijauan yang semakin sempit karena pertumbuhan warga urban yang semakin tinggi yang mengakibatkan tingginya kebutuhan akan rumah. Beberapa kota besar sudah melaksanakan Gerakan ini seperti Palembang, Surabaya, Magelang, Klaten, Yogyakarta, Cilegon, dan Kota Bogor. Gerakan ramah lingkungan ini didukung oleh kebijakan pemerintah yang masif.

Gerakan kampung ramah lingkungan meliputi:

a. Pengendalian kekeringan, banjir dan longsor melalui gerakan penghijauan, pengelolaan sampah dan pembuatan lubang biopori sebagai resapan air.

b. Pengadaan bak sampah dan daur ulang sampah.

c. Pengadaan tanaman vertikultur yang cocok untuk pekarangan sempit dan cocok ditanam di pekarangan rumah.

d. Mengedukasi warga tentang pentingnya ramah lingkungan.

Tujuan utama dari Gerakan Kampung Ramah Lingkungan di Kota Bogor antara lain:

a. Mendorong masyarakat untuk memahami permasalahan lingkungan serta dampaknya.

b. Mendorong masyarakat untuk melakukan tindakan nyata secara proaktif yang berkontribusi kepada upaya perlindungan dan pengelolaan lingkungan hidup.

\subsection{Rumusan Masalah}

Tahun 2017 merupakan tahun di mana program KRL mulai dilaksanakan di Desa Gunung Geulis, hasil dari gerakan peduli lingkungan bisa dilihat dari mulai hijaunya rumah-rumah penduduk dan kebersihan lingkungan yang terjaga dari sampah non organik. Hasil dari penghijauan lingkungan saat ini sudah menghasilkan bibit tanaman yang seharusnya bisa dijual ke masyarakan sekitar atau diluar wilayah Desa Gunung Geulis.

Selain sudah mampu memproduksi bibit tanaman, desa ini juga sudah mampu mengelola sampah organik menjadi pupuk dan mengolah sampah plastik menjadi bubur plastik yang hasilnya dicetak menjadi bata. Namun, dari hasil produksi yang sudah dilakukan oleh Desa Gunung Geulis ternyata belum dimanfaatkan secara optimal untuk menjadi sumber pendapatan rumah tangga. Sebagai destinasi wisata terdekat dari Jakarta, Desa Gunung Geulis harusnya mampu menjadi wisata alternatif bagi wisatawan dengan program KRL-nya.

\subsection{Tujuan dan Manfaat}


Tujuan dari penelitian ini adalah membuka wawasan penduduk yang secara geografis wilayahnya bukan tujuan destinasi wisata menjadi pilihan alternatif wisata berbasis Kampung Ramah Lingkungan. Dan manfaat dari penelitian ini adalah memberi knowledge bagaimana mengelola Kampung Ramah Lingkungan sehingga menjadi sumber pendapatan penduduk.

\section{Metode Penelitian}

Metode penelitian yang digunakan adalah metode kualitatif dengan wawancara langsung kepada narasumber sebanyak 2 (dua) informan, yaitu Iwan dan Yanto yang bertugas sebagai seksi pelaksana harian. Keduanya dianggap memiliki kapasitas sebagai narasumber yang dapat dijadikan referensi.

\section{Pembahasan}

Penelitian berlokasi di RW 02 Desa Gunung Geulis Bogor, tanggal 7 November 2019, dengan informan pertama Yanto sebagai informan utama dan informan kedua adalah Iwan yang merupakan pelaksana program atau warga binaan.

Program Kampung Ramah Lingkungan (KRL) pada Desa Gunung Geulis baru berjalan di tahun 2017 dari sejak dicanangkannya program tersebut di Kabupaten Bogor di tahun 2014.

\section{a. Program KRL}

Pelaksanaan program KRL di wilayah ini sejak tahun 2017 adalah:

1. Mendaur ulang sampah organik dan non organik menjadi bermanfaat di kampungnya. Program sampah daur ulang ini dinaungi oleh Bank Sampah. Produk yang dihasilkan adalah:

- Kompos dari sampah daun dan sisa makanan

- Plastik yang diolah menjadi bata

2. Mengepul dan menyetorkan sampah ke pengepul yang terdiri dari:

- Kertas koran, kardus dan boncos yaitu kertas yang mempunyai nilai paling rendah diantara kertas lainnya

- Sampah plastik yang mempunyai nilai jual disalurkan ke pengepul sampah

- Botol-botol beling

3. Penghijauan rumah warga

- Pembibitan tanaman hias

- Pembibitan sayur mayur

- Menghias lingkungan dengan tanaman hias 


\section{b. Dampak positif KRL}

1. Pemanfaatan lahan kosong menjadi lahan produktif

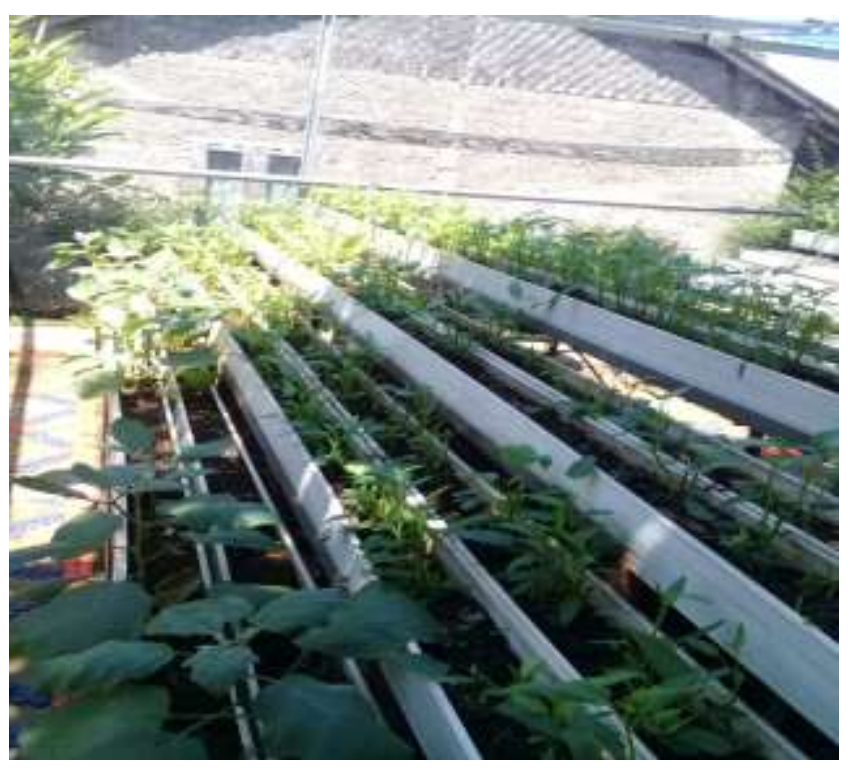

Gambar 1. Pemanfaatan lahan kosong untuk kebun pembibitan sayur mayur

2. Penghijauan jalan lingkungan seperti gang-gang sempit

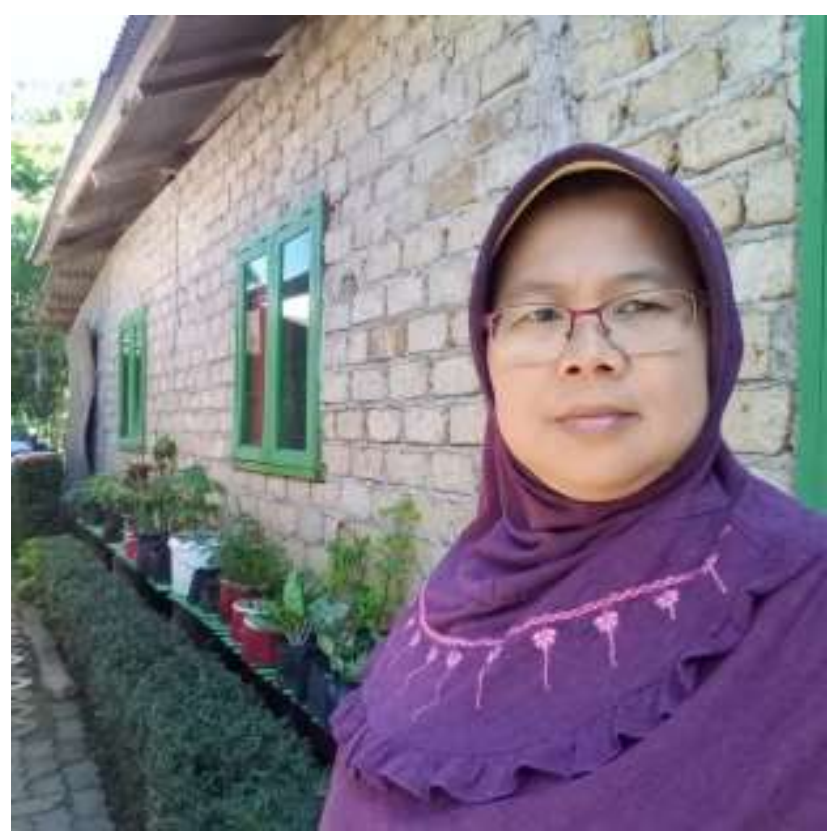

Gambar 2. Penghijauan di gang sempit 
3. Pengembangan bibit tanaman hias

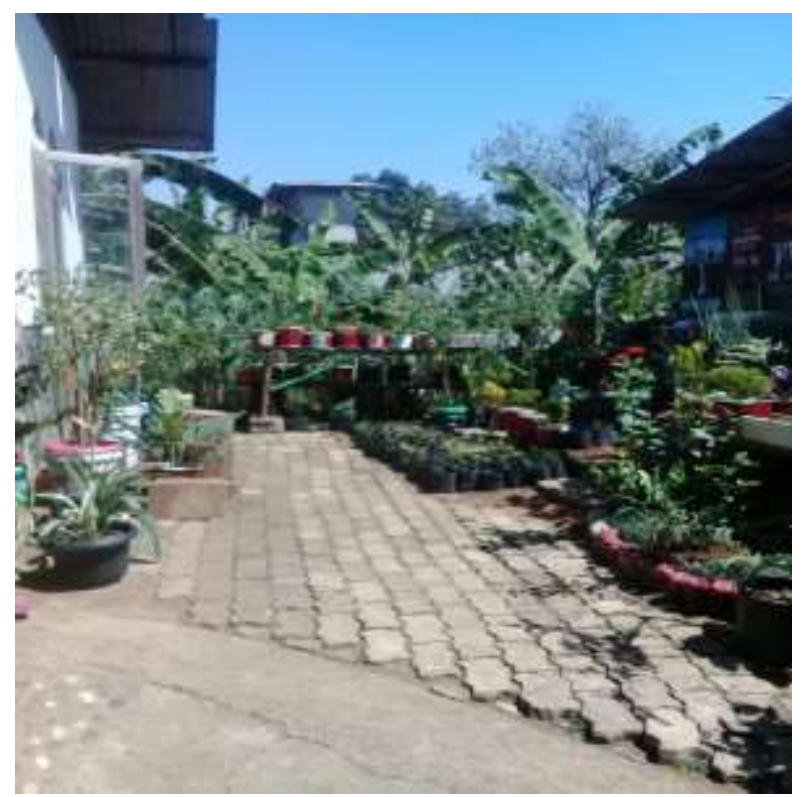

Gambar 3. Pusat pembibitan tanaman hias di RW 02 Desa Gunung Geulis

\section{Peningkatan passive income}

Hasil kegiatan KRL warga secara tidak langsung sudah dapat menghasilkan pendapatan walaupun belum mencukupi secara ekonomis. Pendapatan ini merupakan pendapatan sampingan dari mengumpulkan sampah, membibit tanaman hias dan tanaman sayur mayur serta hasil olahan sampah yang mempunyai nilai jual seperti kompos.

\section{c. Pengelolaan}

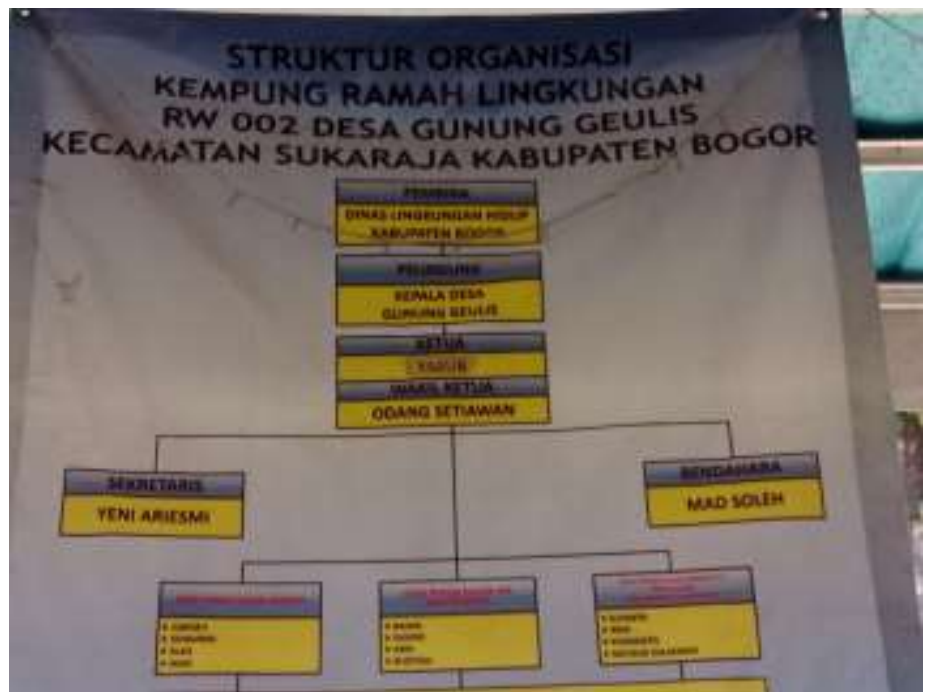

Gambar 4. Struktur organisasi KRL RW 02 Desa Gunung Geulis

\section{Struktur organisasi terdiri dari:}

1. Pembina yang berasal dari Dinas Lingkungan Hidup Kabupaten Bogor

2. Pelindung yang dijabat langsung Kepala Desa Gunung Geulis

3. Ketua dan Wakil Ketua

4. Sekretaris dan Bendahara

5. Pelaksana harian 
Berdasarkan informasi yang didapat dari informan 1, Yanto, pengelolaan saat ini masih dibawah standar karena keterbatasan Sumber Daya Manusia (SDM) yang bertindak sebagai motor penggerak . Belum ada road map dari program KRL yang dilaksanakan saat ini, walaupun sudah pernah diadakan studi banding ke desa wisata di sekitar Ciapus Bogor.

Desa Gunung Geulis adalah wilayah yang memiliki kontur tanah berbukit dan di sekitarnya banyak terdapat area penginapan dan perkemahan yang sebagian besar pengunjungnya adalah dari Jakarta dan wilayah lainnya sekitar kota Bogor. Wisata alam di sekitar Gunung Geulis juga menjadi salah satu daya tarik tersendiri karena letaknya diatas bukit dimana pengunjung dapat memandang hamparan luas lembah dari desa Gunung Geulis. Di sisi jalan banyak terdapat warungwarung yang menyediakan aneka menu makanan yang menjadi kebutuhan para wisatawan. Namun kehadiran wisatawan ini kurang dimanfaatkan oleh warga Desa Gunung Geulis sebagai target pengunjung KRL yang menjadi program andalan desa tersebut. Sebagai salah satu pemenang KRL di Kota Bogor seharusnya mampu mengajak wisatawan berkunjung ke wilayahnya karena memiliki sesuatu yang unik yang tidak dimiliki oleh desa lain, yaitu KRL sebagai desa wisata yang mempunyai nilai edukasi.

Pengurus KRL menyadari bahwa ini menjadi pekerjaan rumah mereka tentang bagaimana desanya bisa dikenal wisatawan sebagai desa wisata kekinian. Dilain pihak mereka juga belum siap dengan infrastruktur yang diperlukan sebagai desa wisata karena terkendala wilayah yang sudah mulai padat rumah penduduk. Untuk akses jalan juga masih terbatas hanya bisa masuk satu mobil dan ini menjadi tantangan bagi mereka bagaimana infrastruktur ini bisa disediakan dan diperbaiki dengan dukungan dari pemerintah Kota Bogor.

\section{Kesimpulan}

Potensi desa wisata berbasis Kampung Ramah Lingkungan di Desa Gunung Geulis sangat terbuka lebar karena alamnya mendukung juga karena ada dukungan dari penduduknya bagaimana mengelola lingkungan sehingga menjadi lebih baik dengan program KRL. Akan tetapi program KRL ini belum didukung untuk menjadi desa wisata karena masih minimnya pengetahuan dan belum adanya pengalaman bagaimana mengembangkan KRL ini menjadi objek wisata bagi wisatawan.

\section{Referensi}

Arismayanti, N. K. (2015). Pariwisata Hijau Sebagai Alternatif Pengembangan Desa Wisata di Indonesia. Hal. 1-15.

Arismayanti, N. K., Ariana, N., Sudana, I. P., Sukana, M., Suwena, I. K., \& Rahyuda, I. (2015). Pelatihan Pengkemasan Paket "Petasan" (Produk Wisata Pedesaan) di Desa Wisata Penglipuran Kecamatan Bangli Kabupaten Bangli Bali. Jurnal Ilmiah Pariwisata, 20 (2).

Komari, A. S. K., Abdulhak, I., \& Heryanto, N. (2011). Sikap Ibu Rumah Tangga Terhadap Penerapan Program Zero Wate Lifestyle di Kelurahan Sukaluyu Kota Bandung 2011.

Putry, A. (2004). Peranan Masyarakat Lokal Dalam Gerakan Sosial "Kampung Ramah Lingkungan” (Studi Kasus di Desa Bojong Gede, Kabupaten Bogor, Jawa Barat).

Sadikin. (2004). Perlawanan Petani, Konflik Agraria, dan Gerakan Sosial. Yayasan AKATIGA. Hal. 19-42.

Taib, R., Endriatmo, S., \& Fredian, T. (2010). Transformasi Identitas Gerakan dari "Petani" menjadi "Masyarakat Adat": 04 (02). Hal. 239-254. 